\title{
Learning Model of Literary Sociology with Contextual and Spiritual Quotient(CSQ) Approach
}

\author{
${ }^{1}$ Masnuatul Hawa, ${ }^{2}$ Andayani, ${ }^{3}$ Suyitno, ${ }^{4}$ Nugraheni Eko Wardani \\ ${ }^{1}$ masnuatulhawaaufa@gmail.com, ${ }^{2}$ bu_anda09@yahoo.co.id, yit_33 suyitno52@yahoo.co.id, \\ ${ }^{4}$ nugraheniekowardani_99@staf.uns.ac.id \\ 1,2,3 Indonesian Language Education Study Program Sebelas Maret University Central Java, Indonesia
}

\begin{abstract}
The course of Literary Theory is a basic course in the field of literature in Indonesian Language Education Study Program. This course is an introduction to analyzing Indonesian literature that discusses the main points of literary theory along with the background of thought that influences theoretical concepts. Literary Sociology is one of the subjects inherent in the study of literary subjects in Indonesian Language Education Study Program in Higher Education context. Learning literary theory, especially the Literary Sociology theory, is still considered boring for most students, therefore, presenting a model of learning with CSQ approach is considered very important to make students active, creative, happy, and have spiritual characters. This research wasa part of Doctoral dissertation research. The purposes of this research were to describe and explain the learning of Literary Sociology theory with CSQ approach. The subject of this research was the students of Indonesian Language Education Study Program. The result of the research shows that learning Literary Sociology theory using CSQ approach can make the students active, creative, joyful, and have spiritual characters indicated by the ability to (1) construct; (2) ask; (3) inquiry; (4) learn in community; (5) have modeling; (6) have reflection; (7) use authentic assessment. The competences of spiritual intelligence that arise in the learning of Literary Sociology with CSQ approach are personal awareness, personal skills, social awareness, and social skills.
\end{abstract}

Keywords: Learning Model; Literary Sociology; CSQ approach.

\section{Introduction}

Teaching literature involves all literary aspects such as literary theory, literary history, literary criticism, comparative literature, and literary appreciation. Among those five aspects, the literary theory becomes fundamental for teaching the other literary aspects. The course of Literary Theory is the basic literary course in all curriculum structure of Language and Literature Education Faculty. This course serves as an introduction for analyzing Indonesian literature focusing on the Literary Theory and its insights.

According to Leslie [1], literature as a learning material or as a human experience devoted to contemplation and assessment that serves to 1) practice four language skills of listening, speaking, reading and writing; 2) develop personality; 3) build the character; 4) provide coziness, safety, and inward satisfaction through human life in fiction; 5) give additional knowledge about human experience in terms of culture, custom, religion, belief, and so forth; 6) enlarge life dimension by new experience obtained from reading literature.

Good literary teaching should be able to carry on four things, i.e. to help with language skills, to improve cultural knowledge, to develop inventiveness and taste, and to support the character building. A meaningful literary teaching is a learning that can be perceived by students either directly or indirectly. The values contained in any literary learning should be able to create an intellectual, emotional, and spiritual experience of the students[2]. 
Hasan[3] states that the values that exist in the literature can be utilized to enrich the growth of students' positive attitudes and behaviors. All of the literary values lead to the formation of students' character as a human being who can behave naturally. The students' existence as human beings is not only as an instinct creature, but also, simultaneously, as a conscious creature who, in turn, makes his behaviors under control. On a wider life scale, in a certain time, the students will be able to channel their instinct and passion of life through the way that does not conflict with their own conscience and feelings.

Literary teaching is not only focused on the material acquisition, but also on the character building, value of internalization, personal development, and even spiritual edification. In other words, literary teaching not only teaches Intellectual Quotient (IQ) and Emotional Quotient (EQ) but also Spiritual Quotient (SQ). SQ becomes the ultimate goal of literary teaching.

The condition of learning Literary Sociology theory in Higher Education has not fulfilled the expectation yet. Lecturers tend to use theoretical and rote learning techniques so that learning activities are rigid, monotonous, and boring. Learning materials of Literary Sociology have not been able to stick to students as something rational, cognitive, emotional, and affective. As a result, the study of Literary Sociology has not been able to attract the students. In fact, if it is implemented correctly, teaching Literary Sociology theory can contribute significantly to the successful development of human, especially the emergence of spiritual intelligence which makes humans have the self-readiness to face the social environment and the field of work.

In order to be able to develop spiritual intelligence, learning Literary Sociology should be supported by the selection of appropriate learning approaches. The contextual teaching and learning approach (CTL) is one of the approaches to teach Literary Sociology theoryin which ables to improve students' spiritual intelligence. This CTL approach applies the learning process by constructing the material based on experience (constructivism), asking, inquiry, learning community, modeling, reflecting, and using authentic assessment. All activities in the contextual approach focus on learning for active and creative students.

\section{Related Works/Literature Review}

\subsection{Learning model}

The success of a literary learning process is the result of the integration of various components of learning. In this case, the lecturer plays an important role as a milestone of learning success. Therefore a lecturer must have competence related to learning materials, mastering various learning models, mastering various learning media, and mastering various learning approaches. Selection of learning models with approaches that make students active and creative is absolutely needed.

Gagne[4] argues that learning process is efforts to encourage students to learn. The learning process will become an event of learning if there is an alteration of students' attitude caused by the interaction of students and environment. To realize it, it is necessary for the lecturers to design a student-centered learning model. Then, the lecturers are as learning designers, motivators, mentors, and assessors.

The word 'model' has three meanings i.e. as noun-model means the representation which has three dimensions in the projected structure; as an adjective-model means perfection or idealization; as a verb-model refers to demonstrate or show the determined thing[5]. Models can facilitate the researcher to understand the activities, but the model also has limitations, among others: too much stress on the symbol, so often it cannot accurately describe a 
symptom, especially in the field of humanities studies. The model also pays attention to form and reliability, simplicity, and illustrates symptoms as maps so that there is a tendency to obtain imprecise and inaccurate images[6].

According to Calhoun [7] there are two types of models, static and dynamic model. The static model tends not to question the changes that occur because of time variables, such as charts, diagrams, and so on. On the contrary, the dynamic model tends to take time as a highly influential variable.

Joyce, Weil, \& Calhoun[8], classify the learning model into four families, namely: (1) information processing family model, (2) personal model, (3) social interaction model, behavioral model (behavioral system family model). According to Joyce, Weil, \& Calhoun (2000: 135), all teaching models contain the following model elements: (1) model orientation, that is the focus or terms of reference concerning the purpose of teaching and environmental aspects; (2) the sequence of activities (syntax), ie stage of action model; (3) social system, ie norm (attitude, skill, understanding) concerning relation between teacher and student, (4) principle of reaction; (5) support system (support system), which supporting instruments to the success of teachers and students such as text, OHP; and (6) instructional and nurturant effect.

The definitions above leads to the conclusion that learning is a plan or pattern used as guidance for designing learning in the class or tutorial learning and functions for determining the learning equipment. As a lecturer, s/he should be able to choose the right learning model for learners. Therefore, in choosing a learning model, lecturers should consider the condition of students, the availability of learning materials and learning resources in order to make the learning model effectively applicable and support the success of learning. A lecturer is expected to possess a sense of renewal and spirit of renewal in the learning process undertaken. The lecturer should have basic teaching competencies, such as opening and closing lessons, explaining materials, making variations of media, asking questions, giving reinforcement, and strategies in applying learning models and approaches.

\subsection{Literary Sociology}

Literary is a science that has been begun since the 3rd century BC, that is when Aristotle (384-322 BC) wrote his book entitled 'Poetica' that contains about the theory of drama tragedy. The term 'poetica', as a theory of literature, is gradually being used with several other terms by literary theorists such as The Study of Literature, by W.H. Hudson, Theory of Literature Rene Wellek and Austin Warren, Literary Scholarship Andre Lafavere, and Literary.

Literary is the disclosure of artistic and imaginative facts as manifestations of human life and society through language as its medium and has a positive effect on human life [9]. Various effects or positive effects that can be felt by the society is the change of human behavior to become a better person in living the life of society.

Another opinion related to the notion of Literary was delivered by Luxemburg [10], in which he states that literary is a science that studies literary texts systematically in accordance with its function in society. The work of literature seeks to present the image of life and life itself. In this case, life includes interpersonal relationships, inter-communities with people, people, and between events that occur within one's mind.

Etymologically [11] says the word literature in the Indonesian language is derived from the Sanskrit root word,Sas-, in a derivative verb means directing, teaching, giving instructions or instructions. The suffix of the word,Tra-, usually indicates the tool, the atmosphere. So the literature is defined as a tool for teaching, instruction manuals, instruction book and teaching. 
From that statement, it is explained that, in fact, every human activity that can produce works that have the value of beauty is categorized as literature, both in the form of writing and oral.

Basically, the science of literature is divided into three parts, i.e. (1) literary theory; literary history; (2) and (3) literary criticism Sarwadi[12], Literature cannot be separated from the parts of the literature. The three branches of the literary sciences are a unified entity in the practice of its use.

Literary Theory is a branch of literature that studies about the principles, laws, categories, criteria of literary works that distinguish them from non-literary ones Sastrowardoyo[13]. Literature Theory is a field of literature that is studied in Higher Education, especially the Indonesian Language Education Study Program. The course of literary theory is given to the first-grade students, the first semester in order to become the basis of early knowledge to learn the next stage of literature.

The course of literary theory learns about various theories and literary approaches. The Literary Sociology is a part of the literary theory studied in the subject of literary theory. The sociology is derived from the word sos (Greek) meaning together, united, friends, and logos means word or parable. Literature from the root of sas (Sanskrit) means directing, teaching, giving instructions or instructions. The suffix of the word,Tra-, usually indicates the tool, the atmosphere. Referring to the definition, both of sociology and literary have the same object, that is human and society. Nevertheless, the essence of sociology and literature is very different even diametrically opposed.

Literary Sociology is a science that has multi-paradigm. It means that in that science are found several paradigms that compete in an attempt to seize hegemony in the field of sociology as a whole. Paradigm itself is defined as a fundamental image of the subject matter in a science. there are three paradigms that form the basis of sociology, i.e. the social facts paradigm, the social definition paradigm, and the social behavior paradigm Ritzer[14].

Swingewood defines sociology as a scientific and objective study of man in society, the study of institutions and social processes. According to Ratna[15], there are a number of definitions of literary sociology to consider in order to find the objectivity of relationships between literature and society, among others: 1) understanding of literary works by considering the aspects of society; 2) understanding the totality of the work accompanied by the social aspect contained; 3) understanding of literary works as well as its relationship with the underlying community; 4) Literary Sociology is a two-way (dialectical) relationship between literature and society; and5) Literary Sociology seeks to discover the interdependence qualities between literature and society.

Sociology, as an approach to literary works, still considers the literary and social aspects. Wellek and Warren[16] divide the Literary Sociology as follows. First, the sociology of the author, the author's profession, and the literary; the related issue here is the foundation of the economic literary production, the social background of the author's status, and the ideology of authors involved from the author's various activities outside the literary work, since each author is a citizen, s/he can be studied as a social being. An author biography is the primary source, but this study may also extend to the neighborhood and originate. In this case, information about the family background, or economic position of the author will have a role in disclosing the author's sociological problem (Wellek and Warren[16].

Secondly, the Literary Sociology works in which the literary work itself is the subject of its study or what is implied in the literary work and what is its purpose. The common approach of sociology is to study literature as a social document and as a portrait of social reality. Wellek and Warren [16] assume, based on the research of Thomas Warton (the first compiler of English poetry history), that literature has the ability to record the characteristics of the 
time. Warton and his literary followers are a repository of customs, a book of historical sources of civilization.

Thirdly, the sociology of literature that concerns the reader and the social impact of literary works, authors are simultaneously influenced by society; art does not only imitate life but also shapes it. Many people imitate the lifestyle of fictional world figures and apply in their life.

The classification of Wellek and Warren[16] is in line with Watt's classification which includes context, literature as the reflection of society, and the social function of literature. The social context of the author, in this case, has to do with the social position of the writer in society, and its relation to the reader society as well as the social factors that may influence his literary work, which must primarily be examined with respect to (a) how the author earned his livelihood, whether he or she gets from direct community guidance, or other work, (b) professionalism in his authorship, and (c) author's intended society.

Literature as a reflection of society means that how far a literature can be considered as a reflection of circumstances in the society. The definition of "reflection" in this case is still vague, therefore, is misinterpreted and misused. What should be considered in the classification of literature as a reflection of society is (a) literature may not be said to reflect society at the time of writing, since many of the characteristics of society displayed in the work are no longer valid when it is written, (b) the different characteristic of an author from one to another often influences the selection and appearance of social facts in his work, (c) the genre of literature is often the social attitudes of a particular group, and not the social attitudes of the whole society; (d) the literature that seeks to display the state of society as closely as possible may not be trusted as a reflection of society.

\subsection{CSQ (Contextual Teaching and Learning and Spiritual Quotient)}

Learning problems in the classroom are very complex. One of the questions encountered by teachers is how to make students understand, relate, and implement difficult concept or theory in the real world. Contextual Teaching and Learning (CTL) is a concept relating the subject content to the lives of a family member, citizen, and labor force Blanchard[17].

Sanjaya[18] states that learning in CTL is not just sitting, listening, taking notes, but learning is a process to get experience directly. Furthermore, it is said that CTL is a learning strategy that emphasizes the full process of student involvement to find the learning material and relate it to real life situations so that students are encouraged to apply it in their lives.

Contextual Teaching and Learning (CTL) is a learning concept that helps teachers connect between material taught to real-world situations of students and encourages students to make connections between their knowledge and application in their lives as family members (US Department of Education, 2001). Contextual Teaching and Learning (CTL) is a holistic learning process aimed at helping students to understand the meaning of teaching materials by relating them to the context of their daily lives (personal, social and cultural contexts) so that students have the dynamic and flexible knowledge or skills to construct their understandings actively.

From some of the above opinions, it can be synthesized that Contextual Teaching and Learning (CTL) is a learning concept that prioritizes students' activeness as the subject of learning through constructing theories with real-life context, inquiry, asking people to learn, modeling, reflecting learning, and use authentic assessment.

According to Johnson[19], some of the major components in contextual learning are: (1) making meaningful connections; (2) doing significant works; (3) self-regulated learning; (4) 
collaborating; (5) critical and creative thinking; (6) nurturing the individual; (7) reaching high standards; and (8) using authentic assessment.

\subsection{Spiritual Quotient (SQ)}

Spiritual intelligence is closely related to the state of one's soul, mind, and spirit. Spiritual intelligence is the highest intelligence of other intelligence such as intellectual intelligence, and emotional intelligence. This is because when people already have spiritual intelligence then the person will be able to interpret life so that it can live with wisdom.

According to Fry[20], the life of one's spirituality has two essential elements: selftranscendence as a manifestation of destiny and the belief that human activity has meaning and value beyond the economic benefit to one's feelings. (Sincerity, forgiveness, kindness, integrity, empathy, honesty, patience, and so on) courage, trust, humility), and faith (endurance, perseverance, and victory).

Spiritual intelligence is the central and most fundamental of all the intelligence because it is the source of guidance of the other three. Spiritual intelligence represents our drive for meaning and connection with infinite ". This opinion asserts that spiritual intelligence is a bridge that can connect and balance the development of other dimensions of intelligence that is naturally given God Covey[21].

Levin[22] says spiritual intelligence is the intelligence that directs our way of thinking toward the innermost essence of human life, which is the servanthood of the Holy and the Great. Spiritual intelligence is defined as the ability of a person's soul to build himself as a whole through a variety of positive activities so as to solve various problems by looking at the meaning contained in it. A person who has spiritual intelligence will be able to solve problems they face by seeing the problem from the positive side so that the problem can be solved well and tend to see a problem from its meaning.

From the above opinions it can be synthesized that spiritual intelligence is the ability to self-correlate to connect beliefs and values to be able to understand the meaning, value, morals, love toward fellow beings because they feel as part of the whole, purpose, and nature of life from which he comes from, for what we live in the world and where we will return.

According to Tischelr[23] there are four competencies derived from spirituality, i.e. (1) personal awareness, that is how one manages himself, self-awareness, emotional selfawareness, positive self-esteem, time competence and self-actualization; (2) personal skills, namely the ability to be independent, flexible, adaptable and show good work performance; (3) social awareness, which shows positive social attitudes, empathy, and altruism; and (4) social skill, that is an ability to have good relation with co-worker and boss, showing attitude open to others, able to cooperate, good recognition to positive and good value in response to criticism.

\section{Material \& Methodology}

This research type is descriptive qualitative. The systematics of this research starts from the planning phase, execution, observation, data collection, data analysis, data interpretation, and description of findings. Research activities were done by identifying the problem, reading, observing, recording and describing the study of Literary Sociology with CSQ approach in Indonesian Language Education Study Program.

The data in this research is a conceptual presentation of the learning process of Literary Sociology with CSQ approach in Indonesian Language Education Study Program. The research techniques used were observation, recording, and analysis. Data validity technique used was triangulation, i.e. data triangulation, method triangulation, and theory triangulation. 
Data analysis techniques used in this study were: 1) data collection; 2) data reduction; 3) data presentation; 4) drawing conclusions.

\section{Results and Discussion}

Based on observation and document study, it can be presented the result of research and discussion of learning model of Literary Sociology with CSQ approach as follows.

\subsection{Constructivism}

Constructivism is the process of building or composing new knowledge in the cognitive structure of students based on experience. This concept requires students to construct and build meaning for new experiences based on certain knowledge. The foundation of constructivism thinking differs from that of the objectivist who put more emphasis on learning outcomes. In constructivism, it prefers the process rather than results.

In learning the material of Literary Sociology, students are trained to be able to construct the concept of Literary Sociology theory with experience owned by the students. Activities that can be done by the students are analyzing social facts of society, social definitions, and social behaviors that are common in society. From the results of the analysis on the social principles of the student, community can build the concept of the theory of Literary Sociology. Learning by constructing experiences and theories will make learning the theory of Literary Sociology more meaningful. The accompaniment impact of constructivism activities is the emergence of spiritual intelligence in the form of personal awareness and independent attitude.

\subsection{Learning Community}

The learning community is a group of learners which functions as a forum for communication to share experiences and ideas. The concept of the learning community in contextual learning suggests that learning outcomes can be obtained through cooperation with others. In this learning community, students in the form of learning groups which purpose is to build social character and a means to share experiences. Group learning activities can simultaneously build students' spiritual intelligence.

The accompaniment impact that arises in the activities of the learning community are: 1) personal awareness; 2) personal skills in the form of independent, flexible, adaptable, and good work performance; 3 ) social awareness, in the form of positive attitude and empathy; 4) social skills, namely the emergence of an open attitude, able to work together, and willing to accept criticism and input from others. Students are prepared to be intelligent humans individually and simultaneously smart in society.

\subsection{Inquiry}

The inquiry is a process of building knowledge/concepts by searching and discovering through a systematic thinking process. This systematic thinking process begins with observation, questioning, investigation, analysis, then building a theory or concept. Inquiry activities are conducted by lecturers assigning students to seek common social principles in the community.

Inquiry activities are conducted through the assignment of students to formulate social facts, social definitions, and social behaviors that occur in the community. From the results of these findings, then, it was analyzed by using the theory of Literary Sociology. The next step, 
students formulate the hypothesis by describing the temporary conclusion based on the data found in the field. Through this inquiry process, students are trained to think systematically, to have a scientific, rational, and logical attitude that is indispensable as the basis for the formation of creativity and the development of spiritual intelligence.

\subsection{Modeling}

Modeling is a process of learning by demonstrating something as an example that every student can imitate. In this concept, the activity of demonstrating a performance is done, so that students can imitate, learn or do something in accordance with the given model. Contextual learning emphasizes the importance of the demonstration of what learners learn.

Each learning group (learning community) is obliged to assign to one of its group members to be a model. In modeling activities, the student is assigned with demonstrating the result of the discussion about social facts, social definitions, and social behavior of the society in front of their friends. develop spiritual intelligence in the form of personal awareness, social awareness, and social skills.

\subsection{Questioning}

Questions and answers can be applied between students and students, teachers with students, students with teachers, or students with other people who come to the class. Questioning activities will be useful for: (1) exploring the students' skills in the mastery of the subject matter, (2) generating students' motivation to learn, (3) stimulating students' curiosity towards something, (4) focusing students on something they want, 5) guide students to find and conclude themselves Syaifudin[24].

Learning of the theory of literary sociology is a meaningful learning theory that is packaged in an interesting way, namely in terms of student learning must be actively involved through Q \& A activities. Question and Answer activities are carried out during the learning community discussion process. Questions made between lecturers with students and students with students can practice listening, thinking, and speaking skills. The accompaniment impact that emerged in this Q \& A activity is self-reliance, self-actualization, positive social attitude, empathy, open attitude, able to cooperate and respond positively to criticism.

\subsection{Reflection}

Reflection is to look back or respond to an event, activities, and experiences that aims to identify things that are known, and things that have not been known in order to be performed an improvement action. Learning reflection is done with the aim to know the shortcomings and advantages of learning sociology literature. The reflection stag becomes the benchmarks and considerations whether a learning process is considered successful or needs to be repeated again. Activities of reflection can be done by lecturers, students, and together (lecturers and students).

\subsection{Authentic Assessment}

Authentic assessment is the process by which the lecturer collects information about student learning progress. In addition, authentic assessment is a term created to explain alternative assessment methods that enable students to demonstrate their ability to complete tasks and solve problems. In the final stages of learning Literary Sociology, the lecturer is responsible for providing assessment during the learning process lasted until the final 
assessment. Assessment of lecturers consists of the cognitive, affective, psychomotor, and spiritual assessment of students.

\section{Conclusion}

Based on the results and discussion, it can be concluded that the learning model of literary sociology with CSQ approach is absolutely needed to be done. Learning model of literary sociology with CSQ approach is more effective and make students creative. It makes students happy and creative in learning. Lecturers should be more creative in choosing a variety of student-centered learning approaches. The cultivation of literary theory concepts will be more meaningful if done by the students constructing their own facts and theories, inquiry, ask the community, modeling, reflection of learning, and authentic assessment.

Learning literary sociology with CSQ approach can improve students' cognitive, affective, psychomotor, and spiritual intelligence. There are four spiritual bits of intelligence that arise in the learning of literary sociology with CSQ approach, namely (1) personal awareness; (2) personal skills; (3) social awareness; and (4) social skill. Spiritual intelligence enables a student to solve every problem of life spiritually that is the ability to meaning every event positively and make contact with God.

\section{Acknowledgement}

We would like to thank Mr. M. Ali Ghufron for his contribution to the English editing.

\section{References}

[1] H. Leslie, Human Brain, Human Learning. New York: Freeman and Co, 1983.

[2] M. H.L.B, The Teaching of Literature. London: Longman, 1971.

[3] Y. Zengin, H. Furkan, and T. Kutluca, "The effect of dynamic mathematics software geogebra on student achievement in teaching of trigonometry," Procedia - Soc. Behav. Sci., vol. 31, no. 2011, pp. 183-187, 2012.

[4] G. Robert. M, Principles of Instructional Design. London: Farmer Press, 1998.

[5] B. Roger T, Analisis Model dalam Sosiolinguistik: Sajian Tujuan pendekatan dan Problem-problemnya. Surabaya: USANA, 2005.

[6] James Bellanca and Ron Brandt, Rethinking How Students Learn, vol. 15. 2010.

[7] C. Bruce, Weil, Marsha, Joyce, \& Emily, Models of Teaching: Model-model Pengajaran, Edisi 8. Yogyakarta: Pustaka Pelajar, 2009.

[8] C. Bruce, Weil, Marsha, Joyce, \& Emily, Models of Teaching. Boston: Library of Congress Cataloging-in-Publication Data, 2000.

[9] E. Mursal, Kesusastraan Pengantar Teori dan sejarah. Bandung: Angkasa Raya, 1978.

[10] L. (dkk) Jan Van, Pengantar Ilmu Sastra. Jakarta: Gramedia, 1984.

[11] E. . Lai, Critical Thinking: A literature Review. Pearson. .

[12] S. Sarwadi, Sejarah Sastra Indonesia Modern. Yogyakarta: Gama Media, 2004. 
[13] S. Subagio, Sekilas Soal Sastra dan Budaya. Jakarta: Balai Pustaka, 1999.

[14] R. George, Sociology: Multiple Paradigm Science. Boston: Allyn and Bacon, Inc, 1975.

[15] R. Nyoman Kutha, Teori, Metode, dan Teknik Penelitian Sastra. Denpasar: Pustaka Pelajar, 2004.

[16] W. Rene, Wellek and Austin, Theory of Literature. New York: Harcourt\& Word, 1968.

[17] G. Lucien, Method in Sociology of Literature. England: Basil Blackwell Publisher, 1981.

[18] S. Wina, Strategi Pembelajaran. Jakarta: Bumi Aksara, 2006.

[19] H. Johnson, A, Privilege, power and difference. New York: McGraw Hill, Inc, 2007.

[20] F. L.W, "Toward a Theory of Spiritual Leadership the Leadership Quarterly," vol. 64, no. 6, 2003.

[21] C. Stephen R, The seven Habits of Highly Effective People. New York: Simon \& Schuster Pte Ltd, 1997.

[22] B. B. Levine, Energizing Teacher Education and Professional Development with Problem Based Learning. United States: Association for Supervision and Curriculum Development, 2001.

[23] O. W. Purbo, “Teknologi e-learning,” Jakarta: Elex Media Komputindo, 2002.

[24] S. B. Djamarah;, Pola Komunikasi Orang Tua \& Anak Dalam Berkeluarga. Rineka Cipta, 2004. 